\title{
New records of Georissus costatus Laporte de Castelnau, 1840 (Coleoptera: Georissidae) from Russia
}

\author{
Новые находки Georissus costatus Laporte de Castelnau, 1840 \\ (Coleoptera: Georissidae) в России
}

\author{
С.В. Аитовкин ${ }^{1}$, М. Фикачек ${ }^{2,3}$ \\ S.V. Litovkin ${ }^{1} \&$ M. Fikáček ${ }^{2,3}$
}

\author{
${ }^{1}$ Russia, Samara; e-mail: sats_lit@pochta.ru. \\ ${ }^{1}$ Россия, Самара. \\ ${ }^{2}$ Department of Entomology, National Museum, Kunratice 1, CZ-148 00 Praha 4, Czech Republic; e-mail: mfikacek@gmail.com. \\ ${ }^{3}$ Department of Zoology, Faculty of Science, Charles University in Prague, Viničná 7, CZ-128 44 Praha 2, Czech Republic.
}

\begin{abstract}
KEY WORDS: Georissidae, Georissus costatus, Russia, new records, sandy shores, riverine habitats.
КЛЮЧЕВЫЕ СЛОВА: Georissidae, Georissus costatus, Россия, новые находки, песчаные берега, речные
\end{abstract} стации.

ABSTRACT. The recent occurrence of Georissus costatus Laporte de Castelnau, 1840 is confirmed in Voronezh, Samara and Orenburg areas for the first time in last 100 years, and its distribution in Russia is clarified. It is shown that the species prefers sandy river shores. Body habitus, aedeagus and locality are figured.

РЕЗЮМЕ. Современными находками из Воронежской, Самарской и Оренбургской областей впервые за 100 лет подтверждено и значительно уточнено распространение в России Georissus costatus Laporte de Castelnau, 1840. Показана приуроченность вида к песчаным речным берегам. Приведены изображения габитуса, эдеагуса и локалитета.

The family Georissidae is distributed world-wide and is represented by 80 described species, which are all assigned to a single genus Georissus Latreille, 1809. The genus is currently divided into three subgenera: Georissus s.str., Neogeorissus Satô, 1972 and Nipponogeorissus Satô, 1972 [Hansen, 1999, 2004; Hebauer, 2004; Fikáček \& Trávníček, 2009; Fikáček \& Falamarzi, 2010]. Both immature stages and adults colonize wet muddy or sandy shores of standing and flowing waters, and are sometimes found near temporary ponds.

The georissid fauna of Russia have not been examined in detail so far. According to the latest estimation [Kirejtshuk, 2001], up to 7 species should occur in Russia - this estimate is based mainly on the Georissus records from adjacent countries. Four species have been recorded in detail in the literature directly from Russia: Georissus crenulatus (Rossi, 1794) is widely distributed from West to the East, G. substriatus Heer, 1841 has been recorded by Motschulsky [1843] (under the name Georissus tenuepunctatus) from Stavropol Province, G. laesicollis Germar, 1824 is found in the
Republic of Adygheya, and G. japonicus Satô, 1972 is found only in southern Primorye [Motschulsky, 1843; Lafer, 1989; Hansen, 1999, 2004; Nikitsky \& Shapovalov, 2010]. The fifth species, Georissus costatus Laporte de Castelnau, 1840 (Figs 1-2), has been only mentioned by Zaitsev [1908] and Jacobson [1913] from the southern part of European Russia without any further details (as "Rossia mer."), and the records are not quoted in later publications [e.g., Hansen, 1999, 2004]. No other records of this species from Russia are known. G. costatus was so far recorded from northern Africa (Algeria, Egypt) [Reiche, 1879; Alfieri, 1976], southern Europe (Spain, France, Italy, Greece) [Hansen, 1999] and Near East (Turkey) [Hansen, 1999]. In this paper, we are providing detailed data based on new findings of $G$. costatus in Russia.

The material was collected during the excursions along the banks of various types of water bodies. At suitable places, water was thrown to the shore and the beetles appearing at the surface were collected using a forceps or an aspirator; the specimens were fixed using $70 \%$ ethanol or killed by ethylacetate. The material was preserved in $70 \%$ ethanol or stretched on mattresses, and then beetles were mounted on entomological pins.

For preliminary identification of species Georissus we used keys of Steffan [1979]. Identification of the specimens was then confirmed by comparison with European collections specimens by M. Fikáček. Photographs of the beetles and the localities were taken using a Sony DSC-W130 camera and the MBS-1 binocular microscope.

In addition to our original findings, we also include the data based on the specimens deposited in the collection of the Zoological Museum of Moscow State 


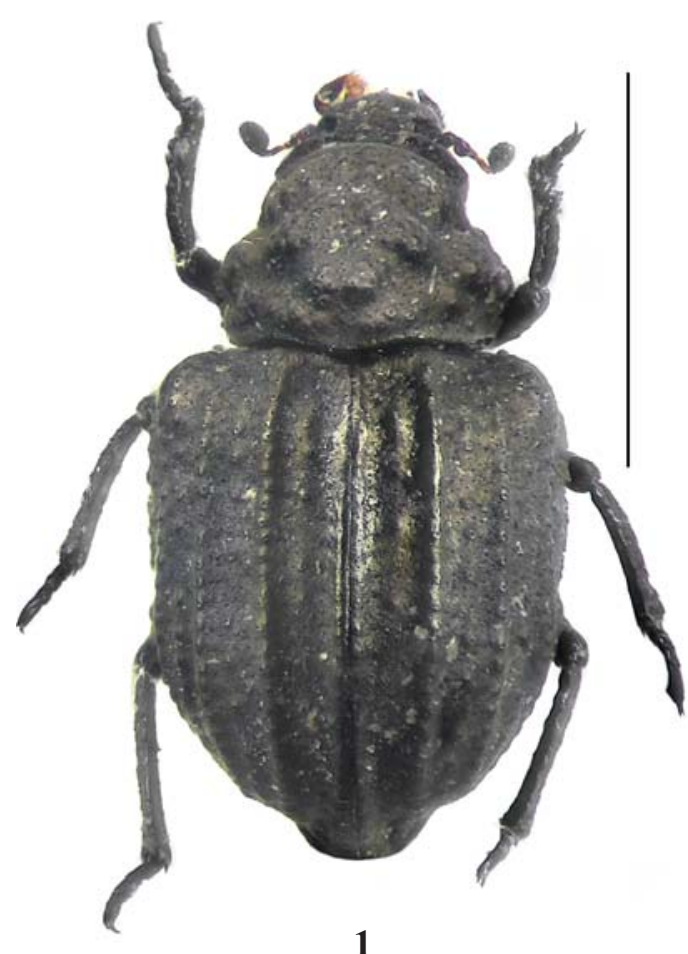

1
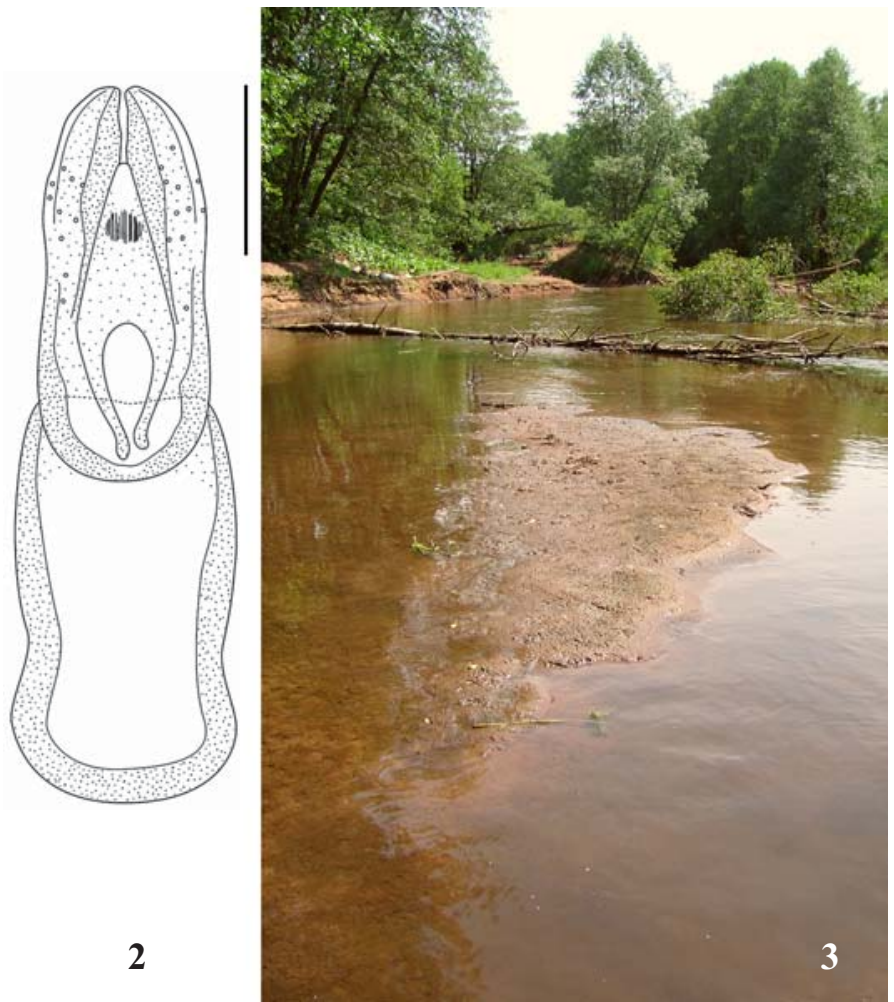

Figs 1-3. Georissus costatus Laporte de Castelnau, 1840: 1 - habitus; 2 - aedeagus; 3 - locality: sandbar on the river Borovka. Scale bars: $1 \mathrm{~mm}$ (habitus); $0.1 \mathrm{~mm}$ (aedeagus).

Рис. 1-3. Georissus costatus Laporte de Castelnau, 1840: 1 - габитус; 2 - эдеагус; 3 - локалитет: песчаная отмель на реке Боровка. Масштабные линейки: 1 мм (габитус); 0,1 мм (эдеагус).

University and on the specimens collected by A.M. Shapovalov.

The studied specimens are stored in the following collections: a private collection of S.V. Litovkin, Samara, Russia (PCL), collection of Zoological Museum of Moscow State University, Moscow, Russia (ZMUM), and the National Museum in Prague, Czech Republic (NMPC).

MATERIAL. Voronezh Area: Khopersky Natural reserve, bank of Khoper river, near the water, 30.07.1974, leg. A.Sharov, [in Russian], [Georissus costatus, det. Gratshev], 1 spec. (ZMUM).

Samara Area: Kinelsky district, Krasnosamarskoe forestry, 10 km SE of Malaya Malyshevka, bank of Samara river: $52^{\circ} 59^{\prime} 03^{\prime \prime} \mathrm{N}$ $51^{\circ} 03^{\prime} 32^{\prime \prime E}$, 15.08.2005, 3 spec., leg. S. Litovkin (PCL); same locality data, but $52^{\circ} 58^{\prime} 57^{\prime \prime} \mathrm{N} 51^{\circ} 03^{\prime} 22^{\prime \prime} \mathrm{E}, 17.08 .2005,2$ spec., leg. $\mathrm{S}$. Litovkin (NMPC); same locality data, but $52^{\circ} 58^{\prime} 57^{\prime \prime N} 51^{\circ} 03^{\prime} 08^{\prime \prime} \mathrm{E}$, 17.08.2005, 1 spec., leg. S. Litovkin (PCL).

Orenburg Area: Buzuluksky district, National Park "Buzuluksky Bor", $17 \mathrm{~km}$ NE of Koltubanovsky village, the confluence of the

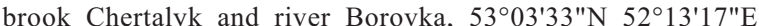
14.06.2010, 36 spec., leg. S. Litovkin (PCL); Kuvandykskiy district, vicinity of Maloe Churaevo village, bank of the Sakmara river, 27.05.2011, 5 spec., leg. A.M. Shapovalov (PCL).

Some beetles were collected at the eroded sandy scree along the high bank of the Samara river, and also at the flat sandy beach. The habitats devoid of vegetation and sediment layers, are well sun-exposed and rarely visited by people, and surrounded by the forest. Collected beetles were not covered by dirt, as is often the case in $G$. crenulatus.
Some beetles were collected at alluvial shore (rough and fine sand with pebbles) of the Sakmara river, in some places with vegetation. The coast is open, but is located near to the forest.

Most of the specimens were collected on a small sandbar in the middle of a small river Borovka (Fig. 3). Some beetles were also collected on the sloping sandy shore. Both habitats devoid of vegetation and sediments. The sandbar is well sun-exposed, but some parts of the coast are sometimes shaded by the trees as the locality is surrounded by the forest. The locality is only rarely visited by people and it is unpolluted. The beetles were not found in other similar localities along the river and streams. Collected beetles were not covered by a layer of dirt and quickly moved on the ground surface.

G. costatus is obviously a psammophilous species preferring undisturbed riverine habitats. This probably can attribute its rare findings in the studied regions.

Our data confirm the occurrence of $G$. costatus in Russia as mentioned by Zaitsev [1908]. Moreover, our records extend range of this species much to the north and east. The rarity, along with the absence of reliable identification keys for Russian Georissus and the specificity of needed collecting methods are apparently the reasons why $G$. costatus is not included in the lists of local faunas so far. 
ACKNOWLEDGEMENS. The authors are grateful to Dr. A.A. Prokin (Voronezh State University, Voronezh, Russia) for his help in preparing the article, to Dr. N.B. Nikitsky (Zoological Museum of Moscow State University, Moscow, Russia) for providing the material of ZMUM for study and to A.M. Shapovalov (Orenburg State University, Orenburg, Russia) for presented material.

\section{References}

Alfieri A. 1976. The Coleoptera of Egypt // Mémoires de la Société Entomologique d’Égypte T.5. P.i-xvi + 1-361.

Fikáček M. \& Trávníček, D. 2009. Georissidae of the United Arab Emirates // A. van Harten (ed.). Arthropod fauna of the UAE. Vol.2. P.145-148.

Fikáček M. \& Falamarzi Sh. 2010. Georissus persicus sp. nov. from Iran, with notes on the West-Palaearctic species of the $G$. laesicollis group (Coleoptera: Georissidae) // Acta Entomologica Musei Nationalis Pragae. Vol. 50. P.107-116.

Jacobson G.G. 1913. [48 family Georyssidae] // Zhuki Rossii zapadnoy Evropy. Rukovodstvo k opredeleniyu zhukov. Saint-Petersburg: A.F. Devrien. Fasc.10. P.861-862 [in Russian].

Hansen M. 1999. Hydrophiloidea (s.str.) (Coleoptera) // World Catalogue of Insects. Vol. 2. Stenstrup: Appolo Books. 416 pp.

Hansen M. 2004. Family Georissidae Laporte, 1840 P.42. // I. Löbl \& A. Smetana (eds.). Catalouge of Palaearctic Coleoptera. Vol.2. Hydrophiloidea, Histeroidea, Staphylinoidea. Stenstrup: Apollo Books.
Hebauer F. 2004. Systematic and zoogeographical notes on the genus Georissus Latreille, 1809 (Coleoptera: Hydrophiloidea) // Acta Coleopterologica. Vol.20. No.1. P.3-6.

Kirejtshuk A.G. 2001. [Coleoptera (Beetles). Key for determination families (on imago)] // S.J. Tsalolikhin (ed.). Opredelitel' presnovodnykh bespozvonochnykh Rossii i prilezhashchikh stran. St. Petersburg: Nauka. Vol.5. P.88-96 [in Russian].

Lafer G.Sh. 1989. [Fam. Georissidae] // P.A. Ler (ed.). Opredelitel' nasekomykh Dal'nego Vostoka SSSR v shesti tomakh. Leningrad: Nauka. Vol.3. Zhestkokrylye, ili zhuki (part 1). P.293-294 [in Russian].

Motschulsky V. 1843. Monographie du genre Georissus Latreille // Bulletin de la Société impériale des naturalistes de Moscou. T.16. P.645-662. Tab.xi-xii.

Nikitsky N.B. \& Shapovalov M.I. 2010. [Family Georissidae] // A.S. Zamotajlov \& N.B. Nikitsky (eds.). Coleopterous insects (Insecta, Coleoptera) of Republic of Adygheya (annotated catalogue of species) (Fauna conspecta of Adygheya. 1). Maykop: Adyghei State University Publishers. P.59 [in Russian].

Reiche L. 1879. Descriptions de quelques nouvelles espèces de Géorissides, Parnides et Hétérocérides propres a la faune européenne // Annales de la Société entomologique de France. Ser.5. T.9. P.237-239.

Steffan A.W. 1979. 43. Familie: Georissidae // H. Freude, K.W. Harde \& G.A. Lohse (eds.). Die Käfer Mitteleuropas. Krefeld: Goecke \& Evers. Bd 6. Diversicornia. P.294-296.

Zaitzev Ph. 1908. Catalogue de Coleopteres agutigues des familles de Dryopidae, Georyssidae, Cyathoceridae, Heteroceridae et Hydrophilidae // Horae Societitas Entomologicae Rossicae. Vol.38. No.4. P.283-420. 